\title{
Be Global, Think and Act Local:
}

\author{
A Response to Eastman \\ Lynda Stone \\ University of North Carolina at Chapel Hill
}

\begin{abstract}
Archaeology is the method specific to the analysis of local discursivities, and genealogy is the tactic which, once it has described these local discursivities, brings into play the desubjugated knowledges that have been released from them.

- Michel Foucault, Society Must be Defended ${ }^{1}$
\end{abstract}

\section{Introduction}

It is an honor to respond to Professor Nicholas Eastman's paper, "Revitalization as Ritual: Sacrifices, Cities, and Schooling." It has given me much to think about present unequal schooling and its underlying conditions in the United States and what across philosophical differences might be done. The title, "Be Global, Think and Act Local," reflects a desire to complement Eastman, to accept a larger modern global order that is entrenched but to try to find a way to combat its excesses through local politics. To begin, Eastman brings together two grand narratives, in an introductory thesis:

[Capitalism is] a religion unto itself, a faith complete with a narrative construction of the human person and his duties toward the higher power in which he lives and moves and has his being. Under capitalism, the human person is reconstituted as a unit of capital formed in the image and likeness 
of the creator. ${ }^{2}$

This response briefly summarizes Eastman's analysis, comments on its strengths, compares the methodology of Eastman with a Foucauldian method, and finally turns to an idea about discourse that Eastman and I might employ together toward political and educational reform. Overall, the paper's analysis is very interesting, especially its discussion of sacrifice within the capitalist-religious thesis and details of the tax structuring in St. Louis and its results.

\section{Eastman's Analysis}

This section recaps elements and strengths of Eastman's analysis to which this response turns to next. First is its recognition of a basis of modern western society in the interplay of the economic and religious. Eastman posits, "Capitalism's reconstitution of being reaches beyond the human person and into the political and geographic landscape." 3 Second is that it brings in a religious tenet of sacrifice and the Israeli philosopher Moshe Halbertal's distinction between "sacrifice to" and "sacrifice for." Third is its major critique of American political theorist Wendy Brown's Foucauldian influenced genealogy of neo-liberalism that builds as well from Halbertal. Eastman offers a useful critique: “[Brown's] analysis is too myopic. Her close examination of the sacrificed individual causes the broader neoliberal political body to remain a blurred outline on the periphery." "Fourth is its detailing of tax incentives to city revitalization as ritual form "in order to secure stability and safeguard global capital's favor into the foreseeable future." 5 The final element is the unique and particular attention to St. Louis.

\section{Response}

The direction of this response can be found in the title. An educational maxim taken from memory recesses is this: "Think global/Act local." Its initial formulation points to the idea of unity and system. The perspective herein rather attempts distinction: one can write and act against a necessary interconnection of a global order and local events, in juxtaposition and more.

To Eastman: First, in this response, a non-universal narrative is held, a nominal conception of political economy in which religion, even perhaps 
fundamentalist, sometimes assists capitalism but remains distinct. Second, there seems no necessary religious conception of sacrifice. Taxes are a form of secular sacrifice, and one wonders if anyone really loves tax time! The issue is what constitutes a moral base, an ethical compass. Generosity, compassion-there surely are other significant ethical views for sharing life and resources with others.

Third, in claiming larger structures, the theoretical focus from Brown and Eastman is on what "individuals" are and how power functions. Perhaps misunderstanding Brown, Eastman's entrepreneurial "caste” actually becomes a traditional "individual” in Alderman Roddy; that a person's local actions mirror the global is at least questionable. Fourth, there are two related queries. One concerns expanding theidea of rituals and their multiple meanings — think about "taking a knee." The other, specific to the St. Louis context is this: How did the inequitable allocation of school funding affect a particular school and the lives of the people therein? Surely there were those who joined together to fight against discrimination. What did they "say and do"? How might a Foucauldian method explore answers?

\section{A Turn to Foucault}

A final step in complementing but offering an alternative to Eastman is to compare methodologies, identified at this point as analytical and discursive. Given Brown's theorizing and even with critique, her Foucauldian methodological project, a genealogy in governmentality, provides direction. Eastman's analytical project concludes this way:

Urban neoliberalization is not a chaotic process of disassociated individuals offering themselves as sacrifices for the economy. Nor are its rituals and power structures reducible to Foucauldian governmentality in which the state is the source and summit of ideology. Rather, neoliberalism is a theo-political faith that forms individuals and a people.... [a] worshipping people organized and disciplined through institutions and political bodies. ${ }^{6}$

Eastman's reading of governmentality perhaps needs recognition of differences from his critical analytic reading. However, he means them differently, he still employs terms such as "power structures," "the state," and "disciplined 
institutions and political bodies" that reside in a particular Foucauldian discourse. Other shared methodological aspects exist. In both, "research" is descriptive and not prescriptive; no suggestion is made of what to do about the inequitable results of a capitalist/neo-liberal social order nor in governmentality. Further, the projects share elements of theory, of the global, and of thinking and acting in the particular, of the local.

What is most significant methodologically, however, is that opposite logics function. Eastman's analytic begins with a global theoretical premise in capitalism, adds or clarifies it with a sub-theory of sacrifice, and then with conceptions of ritual and revitalization. This theory is then applied to a particular local situation, that of the tax situation in St. Louis and its results. In contrast, each of Foucault's genealogies are initiated in a particular context. These range from a historic place, time, and emblematic text, The Prince, in the lecture on governmentality to the torture of Damiens from an actual historic account in Discipline and Punish: The Birth of the Prison. ${ }^{7}$ Both the analytical and discursive genealogy utilize a methodological logic but, significantly, they write in opposition. From their different stances, just as Eastman critiques against a Foucauldian vision from Brown, genealogies are written against. For effect, Foucault writes,

Genealogies are... not positivistic returns to a form of science that is more attentive or more accurate... [They] are quite specifically antisciences.... Genealogy has to fight the power effects characteristic of any discourse regarded as scientific. ${ }^{8}$

In “Governmentality," Foucault takes on Marxism and psychoanalysis as sciences. Not surprising, he would also classify Eastman's philosophy as science.

\section{Discourse for Reform}

In responding to Eastman, the central question that remains concerns what can be done about urban and other locales where schooling is resource poor and remains very unequal. This issue is central but largely implicit to his project to describe the excesses of capitalism as a religion and its effects in a specific political and educational context. First, a comment on capitalism: while providing advantage to those already highly privileged, in a "good" economy 
there is enough improvement for those disadvantaged to engender their often-unquestioning support of the "system" with interests that harm them.?

The epigraph at the outset of this response suggests the importance of discourse in Foucault's writings and its serving as a through-line. Importantly, always it should be remembered that Foucault admonished his readers to do their own work, not to adopt his. One reason as implicated above is its own particularity. Because Foucault describes his projects as distinct axes, they are often taken as separate: different historic contexts, different emergent concepts, and even separate philosophical/historical projects. Throughout his texts, it must be emphasized that discourse is their medium.

Discourse, the specificities of language usage in a historic moment, can be a venue for change. Surely there is always a multiplicity-and in Foucault's projects there are always voices/lives on the margin. Foucault poses that subjugated historical knowledges do operate. He writes, "Disorderly and tattered genealogies... [can] reactivate local knowledges." "The results might well be new body politics or new practices, that in their ways offer opposition to the dominant narratives and practices that Eastman in his way also reveals.

The case of St. Louis, one assumes, continues. This relates to the current political crisis in America. Something has to be done with the daily threats to democracy. Voting is the standard response but with all of its inequities. Today, support for new political movements can bring change but so can working with intimate issues facing people across their own backyards. Speaking, developing, and using different ways of talking, new concepts, and new discourses, and in their "cooperative" multiplicity, have potential. Capitalism as an economy needs to be worked through; generous religious ecumenicalism might also assist.

1 Michel Foucault, "Lecture 7 January 1976," in Society Must Be Defended, Lectures at the College de France, 1975-1976, trans. D. Macey (New York: Picador, 2003), 10-11. The French publication appeared in 1997. The lecture took place 
in the period of publication of his principal genealogies, known in English as Discipline and Punish: The Birth of the Prison and The History of Sexuality: In Introduction, Volume 1.

2 Jean-Francois Lyotard, The Postmodern Condition: A Report on Knowledge, trans. G. Bennington and B. Massumi (Minneapolis, MN: University of Minnesota Press, 1984). The French publication appeared in 1979. In explicating an underlying presence of organizing knowledge, Lyotard's move was to valuing local knowledges; Nicholas Eastman, "Revitalization as Ritual: Sacrifice, Cities, and Schooling," Philosophy of Education 2020, no. 1 (2020).

3 Eastman, "Revitalization as Ritual."

4 Eastman, "Revitalization as Ritual."

5 Eastman, "Revitalization as Ritual."

6 Eastman, "Revitalization as Ritual."

7 Michel Foucault, "Security, Territory, and Population: Lecture at the College de France, 1977-1978," in Michel Foucault, Power, Essential Works of Foucault, Essential Works of Foucault, 1954-1984, Volume 3, ed. James D. Faubion (New York: The Free Press, 2000); Michel Foucault, Discipline and Punish: The Birth of the Prison, trans. A. Sheridan (New York: Vintage, 1979).

8 Foucault, Society Must Be Defended, 9.

9 Thank you to Danny Gibboney for this reminder and other contributions. 10 Foucault, Society Must Be Defended, 10. 